\title{
Climbing Lessons - Inside Outdoor Education
}

\author{
Author and Publisher: Pete McDonald \\ ISBN 0-473-04870-1. 1997. 384 pages. \\ Price: $£ 13+£ 1.50$ p\&p (UK). Available from: \\ Pete McDonald, do 6 Deer Park, Benmore, Dunoon, Argyll PA23 8RB. \\ Reviewed by
}

Bertie Everard

This book is difficult to put down; it is a splendid read, it has only two spelling mistakes and it makes one furiously to think. The author is a master of the English language, with a bias towards its AngloSaxon roots. He wields the sharp weapon of mockery to attack the ex-Graeco-Latin jargon of the behavioural sciences, and a few sacred cows (including some of mine) get butchered on the way.

It is really two books in one. The longer is an engaging description of the author's experiences in taking (mostly 'shitty', as he inelegantly dubs them) kids up hills and down caves - mainly in Derbyshire, UK, where he worked for many years in a famous Local Education Authority outdoor centre, introducing many to outdoor pursuits. He uses this experience to enunciate a challenging and robust philosophy of outdoor education, with a passion that is a joy to behold. He upholds the old traditions of real adventurous experiences which he sees being whittled away by the relentless march of overprescriptive regulations and subverted by the humourless purveyors of psychobabble and the fads of educational theoreticians. What he discerningly writes about this needs to be written in this day and age, when both regulation and intellectual obscurity have gone over the top, at least in Britain; it will doubtless bring cheers from fellow-traditionalists, but is worth taking seriously also by modernists, if they can bring themselves to believe that he may have a point. Truth is, of course, multi-faceted, and Pete McDonald therefore has no monopoly of it. In an ideal world, we would all respect the views and experience of those of contrary opinion, and he is not alone in finding this hard.

The shorter book has the makings of an informative case study in management and organisational behaviour; if professionally written up, it might find a place in in-service education and training courses for outdoor centre managers. As it stands, however, I regard it as unprofessional, in the sense of both 'conduct unbecoming' and 'outwith the author's particular professional competence'. As such, it violates clause 2.7 of the Institute of Outdoor Learning's Code of Professional Conduct and some of the Sport, Recreation and Allied Occupations National Training Organisation (SPRTTO, UK) Value
Statements. Indeed, it might have been alleged to be libellous; I was once threatened with legal action by an aggrieved retired headteacher who figured in a case study in one of my books, despite the fact that I had been careful to conceal his identity by giving his former school a pseudonym. McDonald takes no such care, describing both the centre and its manager by name. In my view, no-one unversed in the theory of organisations is entitled to vilify an individual without first having eliminated all the other possible causes of malfunction. I recall some statistical research showing that only about $20 \%$ of organisational problems can be uniquely attributed to a particular individual; too often disaffected members of organisations indulge in scapegoating and ogre-building in order to account simplistically for what they perceive. I also recall a quotation: 'Every single human being, when the entire situation is taken into account, has always done the very best that he or she could do, and so deserves neither blame nor reproach from anyone, including self'. And there is also: 'Never judge a man before you have walked a mile in his moccasins', doubtless based on the biblical warning, 'Judge not, that ye be not judged'. I guess we all do it from time to time, but there is always a risk involved. Does the risk of giving offence - or worse - really balance the benefit of catharsis and self-justification?

It is sad that an otherwise commendable book should be spoiled by just three out of 26 chapters. It poses a moral dilemma: should one buy it for the valuable insights it provides into the philosophy of outdoor education, or should one refrain from doing so in protest at its accusations? I am glad that, as the reviewer, I was spared the need to make this judgment.

Bertie Everard 